https://helda.helsinki.fi

Low prevalence of zoonotic multidrug-resistant bacteria in veterinarians in a country with prudent use of antimicrobials in animals

\title{
Verkola, Marie
}

2019-09

Verkola , M , Pietola , E , Järvinen , A, Lindqvist, K, Kinnunen , P M \& Heikinheimo , A 2019 , ' Low prevalence of zoonotic multidrug-resistant bacteria in veterinarians in a country with prudent use of antimicrobials in animals ' , Zoonoses and Public Health , vol. 66 , no. 6 , pp. 667-678 . https://doi.org/10.1111/zph.12619

http://hdl.handle.net/10138/316731

https://doi.org/10.1111/zph.12619

unspecified

acceptedVersion

Downloaded from Helda, University of Helsinki institutional repository.

This is an electronic reprint of the original article.

This reprint may differ from the original in pagination and typographic detail.

Please cite the original version. 
Low prevalence of zoonotic multidrug resistant bacteria in veterinarians in a country with prudent use of antimicrobials in animals

LA-MRSA and ESBL-PE in Finnish veterinarians

Marie Verkola $^{\mathrm{a}}$, Eeva Pietola ${ }^{\mathrm{a}}$, Asko Järvinen ${ }^{\mathrm{b}}$, Kristian Lindqvist $^{\mathrm{c}}$, Paula M. Kinnunen ${ }^{\mathrm{d}}$, Annamari Heikinheimo ${ }^{\mathrm{a}}$

${ }^{a}$ Elintarvikehygienian ja ympäristöterveyden osasto, Eläinlääketieteellinen tiedekunta, Helsingin yliopisto, PL 66 (Agnes Sjöbergin katu 2), FI-00014 Helsingin yliopisto, Finland.

'Infektiosairauksien linja, Tulehduskeskus, Helsingin yliopistollinen keskussairaala ja Helsingin yliopisto, PL 340, 00029 HUS, Finland.

${ }^{c}$ Yliopistopalvelut, Lähipalvelutiimi Viikki, Helsingin yliopisto, PL 66 (Agnes Sjöbergin katu 2), FI-00014 Helsingin yliopisto, Finland.

${ }^{d}$ Eläinlääketieteellisten biotieteiden osasto, Eläinlääketieteellinen tiedekunta, Helsingin yliopisto, PL 66 (Agnes Sjöbergin katu 2), FI-00014 Helsingin yliopisto, Finland and Ruokavirasto, Mustialankatu 3, FI-00790 Helsinki, Finland.

*Corresponding author; marie.verkola@helsinki.fi; Tel: +358 (0)50 4486617 


\section{Acknowledgements}

This study was funded by the Finnish Work Environment Fund (project 116105). We thank the Finnish Veterinary Association for enabling the study at the Annual Veterinary Congress and the National Institute for Health and Welfare (Finland) for providing control strains for this study. We are grateful to Tuula Salo, Anu Seppänen, Kirsi Ristkari, Maryama Abdulkadir Adam, Hennariikka Hyytiäinen, Paula Oikarainen, Piela Piilola, Noora Pöytälaakso, Enni Tuutti and Maria Virtanen for technical assistance. The participants are also acknowledged.

\section{Summary}

The occurrence of multidrug resistant, zoonotic bacteria in animals has been increasing worldwide. Working in close contact with livestock increases the risk of carriage of these bacteria. We investigated the occurrence of extended-spectrum beta-lactamase (ESBL) and plasmidic AmpC beta-lactamase producing Enterobacteriaceae (ESBL/pAmpC-PE) and livestock-associated methicillin-resistant Staphylococcus aureus (LA-MRSA) in Finnish veterinarians (n=320). In addition to microbiological samples, background information was collected. Bacterial whole genome sequencing was performed to deduce sequence types (STs), spa types, and resistance genes of the isolates. In total, 3.0\% (9/297) of the veterinarians carried ESBL producing Escherichia coli, with one ESBL producing E. coli isolate producing also AmpC. Seven different STs, sequences of several different plasmid groups as well as several different $b l a_{\mathrm{ESBL} / \mathrm{pAmpC}}$ genes existed in different combinations. No carbapenemase or colistin resistance genes were detected. MRSA was detected in $0.3 \%(1 / 320)$ of the samples. The strain belonged to LA-MRSA clonal complex (CC)398 (ST398, spa type 011, lacking Panton-Valentine leukocidin genes). In conclusion, this study shows low carriage of multidrug resistant zoonotic bacteria in Finnish veterinarians. However, finding LAMRSA for the first time in a sample from a veterinarian in a country with prudent use of animal antimicrobials and regarding the recent rise of LA-MRSA on Finnish pig farms, a strong recommendation to protect people working in close contact with animals carrying LA-MRSA 
CC398 is given. Further studies are needed to explain why the prevalence of LA-MRSA in veterinarians is lower in Finland than in other European countries.

\section{Keywords}

beta-Lactamases, Escherichia coli, Methicillin-Resistant Staphylococcus aureus, Veterinarians, Whole Genome Sequencing

\section{Impacts}

- Occurrence of multiresistant ESBL/pAmpC producing Enterobacteriaceae and LA-MRSA CC398 was studied in veterinarians in Finland.

- First study on ESBL/pAmpC producing Enterobacteriaceae in veterinarians shows low occurrence $(3 \%)$ but whole-genome sequencing revealed high diversity of resistance genes indicating multiple sources.

- $\quad$ This is the first time LA-MRSA CC398 is found from a veterinarian in Finland and regarding the recent rise of LA-MRSA on Finnish pig farms, a strong recommendation to protect people working in close contact with LA-MRSA positive animals is given.

\section{Introduction}

Antimicrobial resistance is a global phenomenon increasing rapidly mainly due to the overuse and misuse of antibiotics in both humans and animals. Highly resistant zoonotic bacteria have emerged in animals, and the World Health Organization has listed several zoonotic bacteria on its global priority list of antibiotic resistant bacteria (WHO, 2017). Between animals and humans, multiresistant bacteria are transmitted through direct contact, or via food or the environment (EFSA \& ECDC, 2018).

Even though evidence is partly contradictory, some studies have reported higher prevalence rates of extended-spectrum beta-lactamase and plasmidic AmpC beta-lactamase producing 
Enterobacteriaceae (ESBL/pAmpC-PE) in people working with farm animals than in the general population (de Been et al., 2014; Dohmen et al., 2015; Huijbers et al., 2014). This indicates that animals could act as a source for human carriage. Determining the source of transmission is difficult as resistance may spread either vertically through bacterial clones (Huijbers et al., 2014) or horizontally via gene transfer (van Duijkeren et al., 2017). Dissemination of resistance genes occurs effectively via extrachromosomal plasmids belonging to several incompatibility (Inc) groups (Carattoli, 2009). Similar Escherichia coli sequence types (STs), ESBL/AmpC genes and plasmids have been found in farmers and animals (Huijbers et al., 2014). Although there are studies on different professions working with animals, veterinarians have not been studied for ESBL/pAmpCPE carriage. In Finland, the proportion of resistant strains in humans is increasing (Jaakola et al., 2017) and ESBL/pAmpC-PE are found both in production and companion animals but still at a low level (EFSA \& ECDC, 2018; Päivärinta, Pohjola, Fredriksson-Ahomaa, \& Heikinheimo, 2016; University of Helsinki, 2017).

In Europe, livestock-associated methicillin-resistant Staphylococcus aureus clonal complex (CC)398 (LA-MRSA) is found in several animal species (Cuny et al., 2010) and has become an important source of human infection (Larsen et al., 2017). In many countries, it is highly prevalent in pigs (Danish Veterinary and Food Administration, 2017; Dierikx et al., 2016). People working with livestock are at increased risk of being colonized with LA-MRSA compared with the rest of the population (Lewis et al., 2008; Van Den Broek et al., 2009). Prevalence of LA-MRSA carriage among veterinarians in different European countries has ranged from $1.4 \%$ up to as high as $44 \%$ (Garcia-Graells et al., 2012; Verkade et al., 2013). Human carriers may transfer LA-MRSA strains to their household members, healthcare facilities and to animals (Grøntvedt et al., 2016; van Cleef et al., 2015). LA-MRSA strains from pigs are usually less virulent than hospital-associated and community-acquired strains, partly due to the fact that they mostly lack the Panton-Valentine leukocidin (PVL) encoding genes and genes of the human immune evasion cluster (Cuny, 
Abdelbary, Layer, Werner, \& Witte, 2015). The majority of LA-MRSA strains are tetracycline and zinc resistant (Cavaco, Hasman, \& Aerestrup, 2011). There are indications that wearing a face mask or dust mask may protect pig farmers and their household members from persistent MRSA carriage and pig farm visitors from contamination with MRSA during short stays (Angen et al., 2019; van Cleef et al., 2015; van Cleef et al., 2014).

In Finland, prevalence of MRSA in human infections has been low, and less than 5\% of invasive S. aureus strains have been methicillin-resistant (Jaakola et al., 2017). In contrast, the occurrence of LA-MRSA has increased rapidly in pigs, reaching 77\% slaughterhouse samples in 2016-2017 (Finresvet 2016-2017, 2018). LA-MRSA CC398 has become more common also in human infections (National Institute for Health and Welfare, 2018), indicating a possible livestock-related transmission route.

The increase of resistant microbes in production animals might serve as a transmission route of these bacteria to the general population in a low human-prevalence setting. Therefore, we studied the occurrence of ESBL/pAmpC-PE and LA-MRSA CC398 in Finnish veterinarians. Background information was collected to assess possible occupational transmission routes, exposure to general risk factors such as travel, antimicrobial therapy, and hospitalisation as well as use of protective equipment. Veterinarians are widely exposed to healthy and infected animals and could be the first ones to show increased carriage rate. Furthermore, self-contamination during routine care occurs frequently among personnel in human hospitals (Krein et al., 2018), and veterinarians are working in conditions where it could be even more common. The chosen whole genome sequencing approach enabled comparison of animal and human strains on the genomic level.

\section{Materials and methods}

Study population 
In December 2016, veterinarians participating in the Annual Veterinary Congress in Helsinki (Finland) were invited to participate in the study. The study was approved by the Coordinating Ethics Committee of the Hospital District of Helsinki and Uusimaa (HUS/1446/2016).

Sample collection and Web form

Nasal and oropharyngeal swabs were taken with two separate swabs (M40 Transystem Amies Agar Gel, Copan Diagnostics, Brescia, Italy) on-site. In addition, participants were given a transport swab for rectal self-sampling and asked to fill in a Web form concerning occupational and recreational risk factors as well as protective measures.

\section{Isolation of Enterobacteriaceae}

Rectal samples were kept at room temperature and transported to the laboratory within 24 hours of sampling. Selective isolation of ESBL, AmpC and carbapenemase producing E. coli and Klebsiella pneumoniae was done following the protocol of the EU Reference Laboratory for Antimicrobial Resistance (EUCAST) (2015). A quality control procedure to validate the selective MacConkey plates was performed using negative control strain E. coli ATCC 25922 and positive control strains E. coli CTX-M-9 (ESBL producer), E. coli CMY-2 (AmpC producer) and E. coli OXA-48 (carbapenemase producer). Single colonies morphologically typical of E. coli or K. pneumoniae were selected, recultivated onto CHROMagar Orientation plates with $1 \mathrm{mg} / \mathrm{ml}$ cefotaxime and incubated for $20-24$ hours at $+37^{\circ} \mathrm{C}$. Single colonies of $E$. coli (light pink) or K. pneumoniae (metallic blue) or colonies of mixed morphology of light pink and metallic blue colour were further cultivated in Columbia bovine blood agar (Columbia blood agar base, Oxoid, Basingstoke, UK) and incubated for $20-24$ hours at $+37^{\circ} \mathrm{C}$.

Species were identified from colony growth on blood agar based on gram staining, an oxidase test and the API 20E test (bioMérieux, Marcy-l'Étoile, France). Strains identified as E. coli or K. pneumoniae were selected for antimicrobial susceptibility testing. 
The nose and oropharyngeal samples were transported to the laboratory at room temperature, pooled and processed within 14 hours of sampling. The samples were incubated in $5 \mathrm{ml}$ MüllerHinton broth (Oxoid, Basingstoke, UK) with $6.5 \% \mathrm{NaCl}$ at $37^{\circ} \mathrm{C}$ overnight. One loopful $(10 \mu \mathrm{l})$ was cultivated on CHROMagar MRSA plates (CHROMagar Microbiology, Paris, France) and incubated at $37^{\circ} \mathrm{C}$ for 24 hours. One typical colony from each plate was subcultured onto bovine blood agar plates (Columbia blood agar base, Oxoid, Basingstoke, UK) and incubated at $37^{\circ} \mathrm{C}$ overnight. Gram staining, coagulase testing (BD BBL Coagulase Plasmas, BD, Franklin Lakes, NJ, USA) and API Staph (BioMérieux, Marcy-l'Étoile, France) were performed to identify S. aureus isolates.

Antimicrobial susceptibility testing

Antimicrobial susceptibility testing of E. coli / K. pneumoniae strains was performed using the disc diffusion method of the European Committee on Antimicrobial Susceptibility Testing (EUCAST) standard $(2013 ;$ 2015). Antimicrobial discs were chosen according to EU legislation (Decision 2013/652/EU) and European Food Safety Authority (EFSA) recommendations (EFSA Panel on Biological Hazards (BIOHAZ), 2011).

Quality control was performed as described for the MacConkey plates. Inhibition zone diameters were measured following EUCAST standard guidelines (2013) and the results interpreted according to EUCAST epidemiological cut-off values (ECOFFs). The double disc synergy test was interpreted as positive if the difference between inhibition zones was $\geq 5 \mathrm{~mm}$.

Isolates resistant to cefotaxime and/or ceftazidime and positive for the double disc synergy test were identified as ESBL producers. Isolates resistant to cefotaxime and/or ceftazidime and cefoxitin, but susceptible to cefepime, were identified as AmpC producers. Isolates resistant to cefotaxime and/or ceftazidime, cefoxitin and cefepime and positive for the double disc synergy test were identified as 
combined ESBL and AmpC producers. Isolates resistant to cefotaxime and/or ceftazidime and meropenem were identified as carbapenemase producers.

For $S$. aureus strains, antimicrobial susceptibility was tested with the disc diffusion method using $30 \mu \mathrm{g}$ cefoxitin discs (Rosco Diagnostica, Taastrup, Denmark). The results were interpreted according to EUCAST ECOFFs. MRSA strains AF 1214-14 MRSA and AF 1582-14 MRSA from the National Institute for Health and Welfare were used as positive reference strains and ATCC 8095 S. aureus and ATCC 25178 S. aureus as negative controls.

DNA extraction and sequencing

DNA of E. coli and S. aureus isolates was extracted and whole genome sequencing was performed on the Illumina HiSeq 4000 platform as paired end with read length of $2 \times 100$ bp and $100 \times$ coverage (CeGaT, Center for Genomics and Transcriptomics, Tübingen, Germany). The quality of DNA pair end read FastQ files was analysed with FastQC (Version 0.10.5-cegat; Andrews, Simon).

Detecting antimicrobial resistance and virulence genes in bacterial whole genome sequence

For ESBL, AmpC or carbapenemase producing E. coli and K. pneumoniae strains, genome assembly was performed with the PATRIC 3.3.18 Assembly Service using SPAdes. SPAdes contigs were run through the Center for Genomic Epidemiology (CGE, Technical University of Denmark, Denmark) databases. Resistance genes were searched using CGE ResFinder 2.1 (Zankari et al., 2012). Plasmid sequences of different incompatibility groups were identified by CGE PlasmidFinder 1.3's (Carattoli et al., 2014) Enterobacteriaceae database. Species identification was confirmed by CGE SpeciesFinder 1.2 (Larsen et al., 2014). Multilocus sequence typing was performed by MLST 1.0 (Larsen et al., 2012) with E. coli \#1 (Wirth et al., 2006) as a reference strain.

For MRSA strains, raw reads were entered into the CGE databases MLST 1.0 (Larsen et al., 2012), spaTyper 1.0 (Bartels et al., 2014), ResFinder 2.1 (Zankari et al., 2012) and VirulenceFinder 1.5 
(Joensen et al., 2014), which performed assembly before analysis for multilocus sequence type, spa type, resistance genes and virulence genes.

Calculation of confidence intervals

Confidence intervals (CIs) for the prevalence of ESBL/AmpC producing E. coli and MRSA in Finnish veterinarians were calculated using the Proportion calculator in www.openepi.com.

\section{Results}

Study population

A total of 320 veterinarians and students with the right to work as a veterinarian (after 5th year of studies) participated in the study by giving a nose and throat swab. The Web form on occupational and recreational risk factors and protective measures was filled in by 262 participants (Table 1). A rectal sample was obtained from 296 participants. All samples were given and the questionnaire filled in by 251 participants.

Prevalence of ESBL/pAmpC producing Enterobacteriaceae

Nine (9/296, 3\%, CI 1.6-5.7\%) veterinarians carried ESBL/pAmpC producing E. coli.

ESBL/pAmpC producing $K$. pneumoniae was not detected. Initially, ten isolates were identified as E. coli by API 20 but one proved susceptible to 3rd generation cephalosporins in susceptibility testing. The other nine isolates were ESBL producers, and one was an AmpC producer as well (Table 2).

Presence of bla $a_{\mathrm{EBL}}$ and $b l a_{\mathrm{pAmpC}}$ genes in Escherichia coli isolates

The ESBL genes detected through whole genome sequencing were $b l a_{\mathrm{CTX}-\mathrm{M}-15}(3 / 9), b_{\mathrm{CTX}-\mathrm{M}-14}$ (2/9), bla $_{\mathrm{CTX}-\mathrm{M}-1}(2 / 9)$, bla $_{\mathrm{CTX}-\mathrm{M}-27}(1 / 9)$ and bla $_{\mathrm{SHV}-12}(1 / 9)$. The only bla $a_{\mathrm{pAmpC}}$ detected was bla ${ }_{\mathrm{CMY}-76}$ carried by an E. coli which also carried bla CTX-M-27 $_{\text {(Table 3). }}$ 
Multilocus sequence types and presence of plasmids in Escherichia coli isolates

STs of ESBL/pAmpC producing E. coli found were ST10 (1/9), ST80 (1/9), ST131 (3/9), ST450 (1/9), ST648 (1/9), ST963 (1/9) and ST1431 (1/9). Plasmids carried by the E. coli included several incompatibility groups. The most common plasmid was IncFII (9/9), carried by all the ESBL/AmpC producing E. coli. Other plasmids detected were IncFI, IncI1, IncR, IncY, IncX and IncB/O/K/Z (Table 3).

Resistance genes detected

The majority $(6 / 9,67 \%)$ of the ESBL/AmpC producing E. coli were multiresistant (resistant to at least three different groups of antimicrobials), with resistance to sulphonamides (9/9), aminoglycosides (6/9) and tetracyclines (6/9) being most prevalent (Table 3). Carbapenem or colistin resistance genes were not detected.

\section{Prevalence of MRSA}

One veterinarian was positive for MRSA carriage (1/320, 0.3\% (CI 0.06-1.7\%)). Phenotypically the strain was coagulase positive and resistant to cefoxitin. The multilocus ST of the strain was ST398 and spa type t011.

On the genomic level, the strain harboured the blaZ and mec $\mathrm{A}$ genes conveying resistance to betalactams as well as the $s p c, n o r \mathrm{~A}, \ln u(\mathrm{~B}), \operatorname{tet}(\mathrm{K}), \operatorname{tet}(\mathrm{M})$ and $d f r \mathrm{G}$ genes associated with resistance to aminoglycosides, fluoroquinolones, lincosamides, tetracyclines (two genes) and trimethoprim, respectively. The results of the analysis for virulence genes are provided in Table 4.

Risk factors and use of protective equipment

Of all veterinarians completing the web form $(n=262), 87.8 \%(230 / 262)$ had travelled abroad during the previous 12 months (Table 1) including travel to ESBL risk regions, with $13.7 \%$ (36/262) travelling to Asia, 1.5\% (4/262) to Africa and 1.5\% (4/262) to South America. Oral 
treatment with antibiotics during the last 6 months was received by 34.9\% (87/249) of veterinarians. Of all respondents, $6.9 \%$ (18/262) shared their households with other healthcare professionals, and $12.2 \%(32 / 262)$ had received hospital treatment at home and $0.8 \%(2 / 262)$ abroad during the previous year.

Altogether 93.5\% (245/262) of participants had work-related animal contact, including contact with live animals, carcasses and samples of animal origin. Among clinicians, companion animal practice was most common, with 59.2\% (155/262) treating companion animals at least weekly and $70.2 \%$ (184/262) treating companion animals less frequently. Production animal practice was most frequently cattle practice, $27.1 \%$ (71/262) having contact weekly and 43.1\% (113/262) more seldom. As many as $98.1 \%$ (257/262) of veterinarians had leisure time animal contact, with dogs, cats and horses being the most prevalent contact animals. The use of a dust mask (Fig. 1) was most common in pig practice and poultry practice with $13.0 \%$ (12/93) and $12.6 \%(6 / 48)$ using a dust mask often or always, respectively.

\section{Discussion}

The present study shows a low carriage rate of multidrug resistant zoonotic bacteria in Finnish veterinarians, although resistance among production animals has rapidly increased during recent years. Despite frequent animal contact during work and leisure time and exposure to multiple other risk factors for multidrug resistant bacteria, the occurrence of both ESBL/pAmpC-PE and MRSA in veterinarians proved low with carriage rates of $3.0 \%$ and $0.3 \%$, respectively.

We observed that travelling abroad and into ESBL risk regions such as Asia, Africa, and Latin America was common among veterinarians (Table 1). Compared to official statistics, Finnish veterinarians are as active travellers as the general population (91\% travelled abroad in 2016) (Official Statistics of Finland, 2017). Oral treatment with antibiotics during the last 6 months was 
also close to the number in the general population (Social Insurance Institution of Finland Kela, 2017).

Veterinarians from many fields of work participated in our study, including clinicians working in large animal and/or companion animal practice, government officers, university lecturers and researchers and meat-inspection veterinarians, among others. Retired veterinarians were eligible as well. Altogether $93.5 \%$ of participants had work-related animal contact, including contact with live animals, carcasses and samples of animal origin. Among clinicians, companion animal practice was most common. Production animal practice was most frequently cattle practice. However, our questions did not address seasonal or other variation in frequency of contact. Neither did we distinguish between conventional and alternative farming in the questions. Nearly all veterinarians had leisure time animal contact, with dogs, cats and horses being the most prevalent contact animals.

Our hypothesis was that as veterinarians work in close contact with animals and/or carcasses of several species and are exposed to infectious material, faeces and secretions on a regular basis, they face an additional ESBL/pAmpC load from animals in addition to the general risk factors such as travel, antibiotic treatment and hospitalisation. The strains found in this study are diverse: the genomic analysis of ESBL/pAmpC E. coli showed multiple different STs, bla $a_{\mathrm{ESBL} / \mathrm{AmpC}}$ genes and plasmid families, indicating that multiple sources of transmission may exist. The source of the strains cannot be determined conclusively despite genome-based analysis of the bacteria and their plasmids. Most of the strains shared the same features as those typically found in humans in previous studies. Three veterinarians carried ESBL E. coli belonging to ST131 and harbouring $b_{\text {bTX-M-15, }}$ bla $a_{\mathrm{CTX}-\mathrm{M}-14}$ or bla $a_{\mathrm{CTX}-\mathrm{M}-27}$. The most prevalent ESBL genes in humans globally are bla $_{\mathrm{CTX}-\mathrm{M}-15}$ and bla $_{\mathrm{CTX}-\mathrm{M}-14}$, but the importance of bla $a_{\mathrm{CTX}-\mathrm{M}-27}$ is growing (Bevan, Jones, \& Hawkey, 2017). These genes are often associated with ST131. While bla $a_{\mathrm{CTX}-\mathrm{M}-15}$ is mainly carried by plasmid family IncF as is bla $a_{\mathrm{CTX}-\mathrm{M}-27}$ in humans, bla $a_{\mathrm{CTX}-\mathrm{M}-14}$ is carried by several plasmid types. Two 


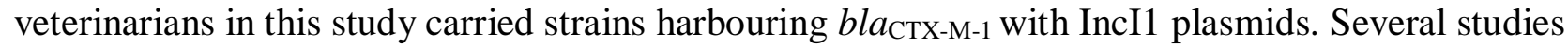
have found such strains in food producing animals (Börjesson et al., 2016; de Been et al., 2014; Päivärinta et al., 2016). However, a strict division into human or animal strains based on resistance genes and plasmid types is not possible (Day et al., 2016). Therefore, this only allows the conclusion that transmission from animals cannot be ruled out, but most of the veterinarians carried other enzyme types than those previously found in Finnish production animals (Päivärinta et al., 2016; Pohjola et al., 2016). According to the background information received from 8/9 carriers, all worked in clinical practice, but no trend was visible in species treated. However, none of the eight carriers worked in poultry practice but two carriers reported infrequent contact to poultry during leisure time. All eight carriers had travelled abroad during the previous 12 months but not to Asia, Africa or Latin America. As many as $67 \%$ of the ESBL/pAmpC producing E. coli strains found in this study were genotypically multiresistant.

According to a recently published study, the prevalence of asymptomatic carriage of ESBL/AmpC producing E. coli and K. pneumoniae in Finland in 2016 was 6.8\% (Rintala et al., 2018). Thus, our results indicate that working as a veterinarian does not increase carriage rates of ESBL/pAmpC-PE. Numbers from other Nordic countries with low occurrence vary from 3.2\% to 4.9\% (Egervärn et al., 2014; Ulstad et al., 2016). Our findings are in line with results of a study conducted in Dutch slaughterhouses which found an overall prevalence equalling that of the general population (Dohmen et al., 2017). In the Dutch study, however, prevalence varied according to the intensity of animal exposure. Differences in intensity of animal exposure might explain why farmers have shown higher prevalence of ESBL/pAmpC-PE (Dohmen et al., 2015; Huijbers et al., 2014), but this did not hold true for veterinarians in this study. Probably a farmer has more intense contact with the animals and contaminated farm environment than a veterinarian visiting the farm for a limited period of time. In addition, prevalence of ESBL/pAmpC-PE in production animals is lower in Finland than in many other European countries (EFSA and ECDC, 2018; Päivärinta et al., 2016). It 
is highest in broiler chickens (8.1-14.7\%). Veterinarians might also protect themselves better from faecal-oral transmission by hand hygiene practices and protective equipment than farmers.

Fortunately, no carbapenem or colistin resistance genes were found in this study. Two carbapenemase positive E. coli were found in two dogs in 2015 (Grönthal et al., 2018), and recently on two occasions colistin resistant strains have been found in street dogs imported from Russia (Finnish Food Safety Authority, 2017; University of Helsinki, 2018). As this study shows how frequent companion animal practice is among veterinarians, the situation should be closely monitored as infection pressure might grow rapidly due to dog imports.

Also, MRSA prevalence in this study proved low: $0.3 \%$ of the veterinarians carried MRSA. The strain belonged to the livestock-associated ST398. To our knowledge, this is the first report of LAMRSA in Finnish veterinarians. The resistance genotype including tetracycline resistance genes tet $(\mathrm{K})$ and tet $(\mathrm{M})$ and spa type $\mathrm{t} 011$, and lack of PVL encoding genes of the strain found, imply that it is genetically related to livestock-associated strains. The veterinarian in question reported pig contact in the questionnaire. However, the MRSA status of the farms visited is not known. Previous studies have shown transmission from pigs to humans (Lewis et al., 2008; Van Den Broek et al., 2009), and studies also show transmission from pig farmers and veterinarians to their household members (van Cleef et al., 2015; Walter et al., 2017).

MRSA prevalence in Finnish veterinarians has been studied before in 2009 (Salmenlinna, Vainio et al. 2010). It was equally low (<1\%) but no MRSA CC398 was detected. In the targeted MRSA surveillance conducted in Finnish healthcare facilities, the proportion of humans colonized or infected with LA-MRSA has risen and was 5.0\% in 2018 (National Institute for Health and Welfare, 2019). As we did not study the pig farms visited by the MRSA carrier, we cannot prove that the veterinarian in question acquired the strain from Finnish pigs. However, keeping in mind the evidence on high risks for LA-MRSA acquisition in frequent pig contact, we recommend measures to protect people working in close contact with pigs, both at farms and slaughterhouses. 
The Finnish Food Safety Authority (2015) has issued a guideline to prevent spread of LA-MRSA in and between pig farms and thus diminish the risk of transmission to humans. Even more emphasis should be put on the public health aspect, to keep LA-MRSA from entering the community and to avoid the spread of LA-MRSA to Finnish hospitals. Several studies indicate that the use of a face or dust mask diminishes the risk of long-term colonization or short-term contamination of humans with LA-MRSA. However, the use of a mask is not mentioned in the guidelines of the Finnish Food Safety Authority (2015). In the web form, $59.1 \%$ of the participants involved in pig practice reported that they never used a dust mask in pig practice. Only $13 \%$ reported using a dust mask often or always. The MRSA carrier belonged to this minority.

In addition to pigs, also contact with other animals has to be considered a possible risk factor for LA-MRSA carriage. In Finland (Salmenlinna, Lyytikäinen, Vainio et al., 2010) as well as in other countries worldwide, MRSA CC398 has been reported in horses (Cuny \& Witte, 2017), which might make veterinarians working with horses another risk group. From our study population, $43.9 \%$ reported work-related contact with horses, and $62.2 \%$ had horse contact during leisure time. Nevertheless, this did not increase the occurrence of MRSA CC398 in our material. The previously reported cases were part of an epidemic in an equine hospital, and it is possible that MRSA is not widespread in Finnish horses. However, now that LA-MRSA has spread in the pig population, it is important to prevent it from spreading to other production and companion animals. Denmark already reports spillover to the mink population most likely via contaminated feed (Hansen et al., 2017).

The present study shows a low carriage rate of multidrug resistant zoonotic bacteria in Finnish veterinarians. Despite frequent occupational animal contact, ESBL/pAmpC-PE prevalence was in line with that in the general population and LA-MRSA CC398 was a rare finding. However, finding LA-MRSA CC398 for the first time from a veterinarian in Finland and considering the recent rise of 
LA-MRSA prevalence in Finnish pigs, we strongly recommend measures to protect people working in close contact with animals carrying LA-MRSA CC398.

It is interesting that although LA-MRSA is frequently found in Finnish pigs, Finnish veterinarians show lower LA-MRSA carriage compared to their colleagues in other European countries. Examples from Finland and Norway show that prudent use of antimicrobials in animals does not seem to prevent the spread of LA-MRSA in animals and further spread to humans working in close contact with these animals (Grøntvedt et al., 2016). Thus, the explanation for low LA-MRSA carriage among Finnish veterinarians must be sought elsewhere. Lower pig density on farms, longer distances between farms and hygiene practices of veterinarians could serve as possible explanations and deserve further studies. The proportion of veterinarians using a dust mask on a regular basis on pig farms seems too low to explain the low prevalence. However, it would be interesting to see studies from other countries in comparison. In any case, it should be kept in mind that in Finland LA-MRSA occurrence in pigs has only recently increased, and therefore there is a possibility that without further action, prevalence among veterinarians will increase in the near future.

\section{Conflicts of Interest}

None to declare.

\section{References}

Angen, O., Skade, L., Urth, T. R., Andersson, M., Baekbo, P., \& Larsen, A. R. (2019). Controlling transmission of MRSA to humans during short-term visits to swine farms using dust masks. Frontiers in Microbiology, 9, 3361. doi:10.3389/fmicb.2018.03361

Bartels, M. D., Petersen, A., Worning, P., Nielsen, J. B., Larner-Svensson, H., Johansen, H. K., . . . Westh, H. (2014). Comparing whole-genome sequencing with Sanger sequencing for spa 
typing of methicillin-resistant Staphylococcus aureus. Journal of Clinical Microbiology, 52, 4305-4308. doi: 10.1128/JCM.01979-14

Bevan, E. R., Jones, A. M., \& Hawkey, P. M. (2017). Global epidemiology of CTX-M betalactamases: Temporal and geographical shifts in genotype. Journal of Antimicrobial Chemotherapy, 72, 2145-2155. doi:10.1093/jac/dkx146

Börjesson, S., Ny, S., Egervärn, M., Bergström, J., Rosengren, A., Englund, S., . . Byfors, S. (2016). Limited dissemination of extended-spectrum beta-lactamase- and plasmid-encoded AmpC-producing Escherichia coli from food and farm animals, Sweden. Emerging Infectious Diseases, 22, 634-640. doi:10.3201/eid2204.151142

Carattoli, A. (2009). Resistance plasmid families in Enterobacteriaceae. Antimicrobial Agents and Chemotherapy, 53, 2227-2238. doi:10.1128/AAC.01707-08

Carattoli, A., Zankari, E., Garcia-Fernandez, A., Voldby Larsen, M., Lund, O., Villa, L., .. . Hasman, H. (2014). In silico detection and typing of plasmids using PlasmidFinder and plasmid multilocus sequence typing. Antimicrobial Agents and Chemotherapy, 58, 3895-3903. doi:10.1128/AAC.02412-14

Cavaco, L. M., Hasman, H., \& Aarestrup, F. M. (2011). Zinc resistance of Staphylococcus aureus of animal origin is strongly associated with methicillin resistance. Veterinary Microbiology, 150, 344-348. doi:10.1016/j.vetmic.2011.02.014

Cuny, C., Abdelbary, M., Layer, F., Werner, G., \& Witte, W. (2015). Prevalence of the immune evasion gene cluster in Staphylococcus aureus CC398. Veterinary Microbiology, 177, 219-223. doi:10.1016/j.vetmic.2015.02.031 
Cuny, C., Friedrich, A., Kozytska, S., Layer, F., Nübel, U., Ohlsen, K., . . Witte, W. (2010). Emergence of methicillin-resistant Staphylococcus aureus (MRSA) in different animal species. International Journal of Medical Microbiology, 300, 109-117. doi:10.1016/j.ijmm.2009.11.002

Cuny, C., \& Witte, W. (2017). MRSA in equine hospitals and its significance for infections in humans. Veterinary Microbiology, 200, 59-64. doi10.1016/j.vetmic.2016.01.013

Danish Veterinary and Food Administration. (2017). Resultaterne af screening for husdyr-MRSA $i$ svin i 2016. Retrieved from https://www.foedevarestyrelsen.dk/Nyheder/Aktuelt/Documents/MRSA\%20ekspertgruppe\%20 -\%20resultatene\%20forekomst\%20af\%20husdyr-MRSA\%20i\%20svin\%202016.pdf

Day, M. J., Rodríguez, I., van Essen-Zandbergen, A., Dierikx, C., Kadlec, K., Schink, A., .. . Woodford, N. (2016). Diversity of STs, plasmids and ESBL genes among Escherichia coli from humans, animals and food in Germany, the Netherlands and the UK. Journal of Antimicrobial Chemotherapy, 71, 1178-1182. doi: 10.1093/jac/dkv485

de Been, M., Lanza, V. F., de Toro, M., Scharringa, J., Dohmen, W., Du, Y., . . van Schaik, W. (2014). Dissemination of cephalosporin resistance genes between Escherichia coli strains from farm animals and humans by specific plasmid lineages. PLoS Genetics, 10(12), e1004776. doi: 10.1371/journal.pgen.1004776

Decision 2013/652/EU. Commission implementing decision of 12 November 2013 on the monitoring and reporting of antimicrobial resistance in zoonotic and commensal bacteria [2013] OJ, L303/26. doi: 10.3000/19770677.L_2013.303.eng

Dierikx, C. M., Hengeveld, P. D., Veldman, K. T., de Haan, A., van der Voorde, S., Dop, P. Y., . . . van Duijkeren, E. (2016). Ten years later: Still a high prevalence of MRSA in slaughter pigs 
despite a significant reduction in antimicrobial usage in pigs the Netherlands. Journal of Antimicrobial Chemotherapy, 71, 2414-2418. doi: 10.1093/jac/dkw190

Dohmen, W., Bonten, M. J. M., Bos, M. E. H., van Marm, S., Scharringa, J., Wagenaar, J. A., \& Heederik, D. J. J. (2015). Carriage of extended-spectrum $\beta$-lactamases in pig farmers is associated with occurrence in pigs. Clinical Microbiology and Infection, 21, 917-923. doi: 10.1016/j.cmi.2015.05.032

Dohmen, W., Van Gompel, L., Schmitt, H., Liakopoulos, A., Heres, L., Urlings, B. A., . . Heederik, D. J. J. (2017). ESBL carriage in pig slaughterhouse workers is associated with occupational exposure. Epidemiology and Infection, 145, 2003-2010. doi: $10.1017 / \mathrm{S} 0950268817000784$

EFSA Panel on Biological Hazards (BIOHAZ). (2011). Scientific opinion on the public health risks of bacterial strains producing extended-spectrum $\beta$-lactamases and/or AmpC $\beta$-lactamases in food and food-producing animals. EFSA Journal, 9, 2322. doi: 10.2903/j.efsa.2011.2322

EFSA, \& ECDC. (2018). The European Union summary report on antimicrobial resistance in zoonotic and indicator bacteria from humans, animals and food in 2016. EFSA Journal, 16, e05182. doi: $10.2903 /$ j.efsa.2018.5182

Egervärn, M., Rosengren, Å, Englund, S., Börjesson, S., Löfmark, S., Ny, S. \& Byfors, S. (2014). Slutrapport från ett myndighetsgemensamt projekt - antibiotikaresistens. ESBL-bildande E.coli $i$ vår omgivning - livsmedel som spridningsväg till människa. Retrieved from http://www.sva.se/globalassets/redesign2011/pdf/antibiotika/antibiotikaresistens/msb-esblslutrapport.pdf 
EUCAST. (2013). EUCAST guidelines for detection of resistance mechanisms and specific resistances of clinical and/or epidemiological importance. Version 1.0. Retrieved from http://www.amcli.it/wpcontent/uploads/2015/10/EUCAST_detection_resistance_mechanisms_V1.pdf

EUCAST. (2015). Antimicrobial susceptibility testing. EUCAST disk diffusion method. Version 5.0. Retrieved from http://www.eucast.org/fileadmin/src/media/PDFs/EUCAST_files/Disk_test_documents/Manual _v_5.0_EUCAST_Disk_Test.pdf

Finnish Food Safety Authority (2015). Ajankohtaista MRSA-bakteerista sikatiloilla. [Current issues about MRSA]. Retrieved from https://www.ruokavirasto.fi/globalassets/viljelijat/elaintenpito/elainten-laakitseminen/mrsaohje_sikatiloille_20150121_su.pdf

Finnish Food Safety Authority. (2017). Suomessa todettu kolistiiniresistenssiä tuontikoirasta. [Colistin resistance detected in imported dog in Finland]. Retrieved from https://www.ruokavirasto.fi/teemat/zoonoosikeskus/uutiset/2017/suomessa-todettukolistiiniresistenssia-tuontikoirasta/

FINRES-Vet 2016-2017. (2018). Finnish veterinary antimicrobial resistance monitoring and consumption of antimicrobial agents. Retrieved from https://www.ruokavirasto.fi/globalassets/viljelijat/elaintenpito/elaintenlaakitseminen/evira_publications_5_2018.pdf

Garcia-Graells, C., Antoine, J., Larsen, J., Catry, B., Skov, R., \& Denis, O. (2012). Livestock veterinarians at high risk of acquiring methicillin-resistant Staphylococcus aureus ST398. Epidemiology and Infection, 140, 383-389. doi: 10.1017/S0950268811002263 
Grönthal, T., Österblad, M., Eklund, M., Jalava, J., Nykäsenoja, S., Pekkanen, K., \& Rantala, M. (2018). Sharing more than friendship - transmission of NDM-5 ST167 and CTX-M-9 ST69 Escherichia coli between dogs and humans in a family, Finland, 2015. Euro Surveillance, 23(27), 7917.ES.2018.23.27.1700497. doi:10.2807/15607917.ES.2018.23.27.1700497

Grøntvedt, C. A., Elstrøm, P., Stegger, M., Skov, R. L., Skytt Andersen, P., Wik Larssen, K., . . Bjørnholt, J. V. (2016). MRSA CC398 in humans and pigs in Norway: A "one health" perspective on introduction and transmission. Clinical Infectious Diseases: An Official Publication of the Infectious Diseases Society of America, doi:10.1093/cid/ciw552

Hansen, J. E., Larsen, A. R., Skov, R. L., Chriel, M., Larsen, G., Angen, O., . . Pedersen, K. (2017). Livestock-associated methicillin-resistant Staphylococcus aureus is widespread in farmed mink (Neovison vison). Veterinary Microbiology, 207, 44-49. doi: 10.1016/j.vetmic.2017.05.027

Huijbers, P. M. C., Graat, E. A. M., Haenen, A. P. J., van Santen, M. G., van Essen-Zandbergen, A., Mevius, D. J., . . van Hoek, A. H. A. M. (2014). Extended-spectrum and AmpC $\beta$-lactamaseproducing Escherichia coli in broilers and people living and/or working on broiler farms: Prevalence, risk factors and molecular characteristics. Journal of Antimicrobial Chemotherapy, 69, 2669-2675. doi: 10.1093/jac/dku178

Jaakola, S., Lyytikäinen, O., Rimhanen-Finne, R., Salmenlinna, S., Savolainen-Kopra, C., Liitsola, K., . . . Salminen, M. (2017). Tartuntataudit Suomessa 2016. [Infectious diseases in Finland 2016]. Retrieved from http://urn.fi/URN:ISBN:978-952-302-890-6

Joensen, K. G., Scheutz, F., Lund, O., Hasman, H., Kaas, R. S., Nielsen, E. M., \& Aarestrup, F. M. (2014). Real-time whole-genome sequencing for routine typing, surveillance, and outbreak 
detection of verotoxigenic Escherichia coli. Journal of Clinical Microbiology, 52, 1501-1510. doi: 10.1128/JCM.03617-13

Krein, S. L., Mayer, J., Harrod, M., Weston, L. E., Gregory, L., Petersen, L., . . Drews, F. A. (2018). Identification and characterization of failures in infectious agent transmission precaution practices in hospitals: A qualitative study. JAMA Internal Medicine 178,1051-1057, doi: 10.1001/jamainternmed.2018.1898

Larsen, J., Petersen, A., Larsen, A. R., Sieber, R. N., Stegger, M., Koch, A., . . Skov, R.L. (2017). Emergence of livestock-associated methicillin-resistant Staphylococcus aureus bloodstream infections in Denmark. Clinical Infectious Diseases 65, 1072-1076. doi: 10.1093/cid/cix504

Larsen, M. V., Cosentino, S., Lukjancenko, O., Saputra, D., Rasmussen, S., Hasman, H., . . Lund, O. (2014). Benchmarking of methods for genomic taxonomy. Journal of Clinical Microbiology, 52, 1529-1539. doi: 10.1128/JCM.02981-13

Larsen, M. V., Cosentino, S., Rasmussen, S., Friis, C., Hasman, H., Marvig, R. L., . . Lund, O. (2012). Multilocus sequence typing of total-genome-sequenced bacteria. Journal of Clinical Microbiology, 50, 1355-1361. doi: 10.1128/JCM.06094-11

Lewis, H. C., Molbak, K., Reese, C., Aarestrup, F. M., Selchau, M., Sorum, M., \& Skov, R. L. (2008). Pigs as source of methicillin-resistant Staphylococcus aureus CC398 infections in humans, Denmark. Emerging Infectious Disease Journal, 14, 1383. doi: 10.3201/eid1409.071576

National Institute for Health and Welfare. (2019). MRSA esiintyvyys. [Occurrence of MRSA]. Retrieved from https://thl.fi/fi/web/infektiotaudit/seuranta-ja- 
epidemiat/tartuntatautirekisteri/tartuntataudit-suomessa-vuosiraportit/tautien-esiintyvyys/mrsaesiintyvyys

Official Statistics of Finland. (2017). Finnish travel 2016. Retrieved from https://www.stat.fi/til/smat/2016/smat_2016_2017-03-29_en.pdf

Päivärinta, M., Pohjola, L., Fredriksson-Ahomaa, M., \& Heikinheimo, A. (2016). Low occurrence of extended-spectrum $\beta$-lactamase-producing Escherichia coli in Finnish food-producing animals. Zoonoses and Public Health, 63, 624-631. doi: 10.1111/zph.12277

Pohjola, L., Nykasenoja, S., Kivisto, R., Soveri, T., Huovilainen, A., Hanninen, M. L., \& Fredriksson-Ahomaa, M. (2016). Zoonotic public health hazards in backyard chickens. Zoonoses and Public Health, 63, 420-430. doi: 10.1111/zph.12247

Rintala, E., Gröndahl-Yli-Hannuksela, K., Lönnqvist, E., Talja, M., Rantakokko-Jalava, K., \& Vuopio, J. (2018). ESBL:ää tuottavien suolistobakteerien oireeton kantajuus EteläSuomessa. [Asymptomatic ESBL carriage in Southern Finland]. Lääkärilehti, 73(43), 25032508.

Salmenlinna, S., Lyytikäinen, O., Vainio, A., Myllyniemi, A. L., Raulo, S., Kanerva, M., . . . Vuopio, J. (2010). Human cases of methicillin-resistant Staphylococcus aureus CC398, Finland. Emerging Infectious Diseases, 16, 1626-1629. doi: 10.3201/eid1610.091571

Salmenlinna, S., Vainio, A., Kanerva, M., Vuopio-Varkila, J., Myllyniemi, A. -L., Raulo, S., . . Lyytikäinen, O. (2010). Metisilliiniresistentti Staphylococcus aureus (MRSA) CC398 eläimillä ja ihmisillä. [Methicillin resistant Staphylococcus aureus (MRSA) CC398 in animals and humans.] Sairaalahygienialehti, 28, 9-13. 
Social Insurance Institution of Finland Kela. (2017). Kelan tilastollinen vuosikirja 2016. [Statistical yearbook of the Social Insurance Institution 2016]. Retrieved from http://urn.fi/URN:NBN:fife201802093282

Ulstad, C. R., Solheim, M., Berg, S., Lindbaek, M., Dahle, U. R., \& Wester, A. L. (2016). Carriage of ESBL/AmpC-producing or ciprofloxacin non-susceptible Escherichia coli and Klebsiella spp. in healthy people in Norway. Antimicrobial Resistance and Infection Control, 5, 1-11. doi: $10.1186 / \mathrm{s} 13756-016-0156-\mathrm{x}$

University of Helsinki. (2017). Moniresistentit bakteerit ovat tuontikoirilla huolestuttavan yleisiä [Multiresistant bacteria alarmingly common in imported dogs]. Retrieved from https://www.helsinki.fi/fi/uutiset/terveys/moniresistentit-bakteerit-ovat-tuontikoirillahuolestuttavan-yleisia

University of Helsinki. (2018). Colistin resistance detected in shelter dogs imported from Russia. Retrieved from https://www.helsinki.fi/en/news/health/colistin-resistance-detected-in-shelterdogs-imported-from-russia

van Cleef, B. A., van Benthem, B. H., Verkade, E. J., van Rijen, M. M., Kluytmans-van den Bergh, M. F., Schouls, L. M., . . Kluytmans, J. A. (2014). Dynamics of methicillin-resistant staphylococcus aureus and methicillin-susceptible staphylococcus aureus carriage in pig farmers: A prospective cohort study. Clinical Microbiology and Infection, 20, 764771. doi:10.1111/1469-0691.12582

van Cleef, B. A., van Benthem, B. H., Verkade, E. J., van Rijen, M. M., Kluytmans-van den Bergh, M. F., Graveland, H., . . Kluytmans, J. A. (2015). Livestock-associated MRSA in household 
members of pig farmers: Transmission and dynamics of carriage, a prospective cohort study. PloS One, 10, e0127190. doi: 10.1371/journal.pone.0127190

Van Den Broek, I. V., Van Cleef, B. A., Haenen, A., Broens, E. M., Van Der Wolf, P. J., Van Den Broek, M. J., . . Tiemersma, E. W. (2009). Methicillin-resistant Staphylococcus aureus in people living and working in pig farms. Epidemiology and Infection, 137, 700-708. doi: 10.1017/S0950268808001507

van Duijkeren, E., Wielders, C. C. H., Dierikx, C. M., van Hoek, A. H. A. M., Hengeveld, P., . . de Greef, S. C. (2017). Long-term carriage of extended-spectrum $\beta$-Lactamase-Producing Escherichia coli and Klebsiella pneumoniae in the general population in the Netherlands. Clinical Infectious Diseases, doi: 10.1093/cid/cix1015

Verkade, E., van Benthem, B., den Bergh, M. K., van Cleef, B., van Rijen, M., Bosch, T., \& Kluytmans, J. (2013). Dynamics and determinants of Staphylococcus aureus carriage in livestock veterinarians: A prospective cohort study. Clinical Infectious Diseases, 57(2), e11e17. doi: $10.1093 / \mathrm{cid} / \mathrm{cit} 228$

Walter, J., Espelage, W., Adlhoch, C., Cuny, C., Schink, S., Jansen, A., . . Hermes, J. (2017). Persistence of nasal colonisation with methicillin resistant Staphylococcus aureus CC398 among participants of veterinary conferences and occurrence among their household members: A prospective cohort study, Germany 2008-2014. Veterinary Microbiology, 200, 13-18. doi: 10.1016/j.vetmic.2016.03.015

WHO. (2017). Global priority list of antibiotic-resistant bacteria to guide research, discovery, and development of new antibiotics. Retrieved from http://www.who.int/medicines/publications/global-priority-list-antibiotic-resistant-bacteria/en/ 
Wirth, T., Falush, D., Lan, R., Colles, F., Mensa, P., Wieler, L. H., . . Achtman, M. (2006). Sex and virulence in Escherichia coli: An evolutionary perspective. Molecular Microbiology, 60, 1136-1151. doi: 10.1111/j.1365-2958.2006.05172.x

Zankari, E., Hasman, H., Cosentino, S., Vestergaard, M., Rasmussen, S., Lund, O., . . Larsen, M. V. (2012). Identification of acquired antimicrobial resistance genes. Journal of Antimicrobial Chemotherapy, 67, 2640-2644. doi: 10.1093/jac/dks261 
Table 1. Background characteristics, risk factors, and carriage of MRSA and ESBL of veterinarians participating in the study and submitting the Web form $(\mathrm{n}=262)$.

\begin{tabular}{|c|c|c|c|c|}
\hline \multirow[t]{2}{*}{ Category } & \multirow[t]{2}{*}{ Subcategory } & \multirow[t]{2}{*}{ No. $(\%)$ of participants } & \multicolumn{2}{|c|}{ No. of carriers } \\
\hline & & & $\begin{array}{l}\text { MRSA } \\
(\mathrm{n}=1)\end{array}$ & $\begin{array}{l}\text { ESBL/pAmpC-PE } \\
(\mathrm{n}=8)\end{array}$ \\
\hline \multicolumn{5}{|l|}{ General characteristics } \\
\hline \multirow[t]{3}{*}{ Gender } & female & $230(87.8)$ & - & 5 \\
\hline & male & $30(11.5)$ & - & 3 \\
\hline & not disclosed & $2(0.8)$ & - & 0 \\
\hline \multirow{3}{*}{ Years since graduation } & $0-9$ & $112(42.7)$ & - & 0 \\
\hline & $10-20$ & $76(29.0)$ & - & 5 \\
\hline & $>20$ & $74(28.2)$ & - & 3 \\
\hline \multirow[t]{2}{*}{ Location of veterinary education } & Helsinki, Finland & $236(90.1)$ & - & 8 \\
\hline & Abroad & $26(9.9)$ & - & 0 \\
\hline \multicolumn{5}{|l|}{ Animal-related risk factors } \\
\hline \multirow[t]{2}{*}{ Work-related animal contact ${ }^{\dagger}$} & Yes & $245(93.5)$ & 1 & 8 \\
\hline & No & $17(6.5)$ & 0 & 0 \\
\hline \multirow[t]{6}{*}{ Type of animal contact } & Pig practice & $77(29.4)$ & 1 & 2 \\
\hline & Cattle practice & $113(43.1)$ & 1 & 4 \\
\hline & Poultry practice & $42(16.0)$ & 0 & 0 \\
\hline & Fur animal practice & $11(4.2)$ & 0 & 0 \\
\hline & Equine practice & $115(43.9)$ & 0 & 3 \\
\hline & $\begin{array}{l}\text { Companion animal } \\
\text { practice }\end{array}$ & $184(70.2)$ & 0 & 6 \\
\hline \multirow[t]{6}{*}{ Type of frequent ${ }^{\ddagger}$ animal contact } & Pig practice & $17(6.5)$ & 0 & 1 \\
\hline & Cattle practice & $71(27.1)$ & 0 & 2 \\
\hline & Poultry practice & $7(2.7)$ & 0 & 0 \\
\hline & Fur animal practice & $0(0.0)$ & 0 & 0 \\
\hline & Equine practice & $41(15.6)$ & 0 & 3 \\
\hline & $\begin{array}{l}\text { Companion animal } \\
\text { practice }\end{array}$ & $155(59.2)$ & 0 & 1 \\
\hline
\end{tabular}




\begin{tabular}{|c|c|c|c|c|}
\hline \multirow[t]{2}{*}{ Work-related animal contact abroad } & Yes & $21(8.0)$ & 0 & 1 \\
\hline & No & $241(92.0)$ & 0 & 0 \\
\hline \multirow[t]{2}{*}{ Leisure time animal contact } & Yes & $257(98.1)$ & 0 & 8 \\
\hline & No & $5(1.9)$ & 1 & 0 \\
\hline \multirow[t]{7}{*}{ Type of leisure time animal contact ${ }^{\S}$} & Pigs & $27(10.3)$ & 0 & 2 \\
\hline & Cattle & $76(29.0)$ & 0 & 3 \\
\hline & Poultry & $42(16.0)$ & 0 & 2 \\
\hline & Fur animals & $2(0.8)$ & 0 & 0 \\
\hline & Horses & $163(62.2)$ & 0 & 4 \\
\hline & Dogs & $251(95.8)$ & 0 & 8 \\
\hline & Cats & $219(83.6)$ & 0 & 8 \\
\hline \multirow[t]{7}{*}{ Frequent ${ }^{\ddagger}$ leisure time animal contact } & Pigs & $4(1.5)$ & 0 & 1 \\
\hline & Cattle & $10(3.8)$ & 0 & 1 \\
\hline & Poultry & $12(4.6)$ & 0 & 0 \\
\hline & Fur animals & $0(0.0)$ & 0 & 0 \\
\hline & Horses & $68(26.0)$ & 0 & 2 \\
\hline & Dogs & $179(68.3)$ & 0 & 6 \\
\hline & Cats & $114(43.5)$ & 0 & 6 \\
\hline \multirow[t]{2}{*}{ Occupation of household member } & $\begin{array}{l}\text { Veterinarian/ veterinary } \\
\text { technician }\end{array}$ & $27(10.3)$ & 0 & 1 \\
\hline & $\begin{array}{l}\text { Other profession with } \\
\text { animal contact }\end{array}$ & $24(9.2)$ & 0 & 0 \\
\hline \multicolumn{5}{|l|}{ Travel-related risk factors } \\
\hline \multirow[t]{2}{*}{ International travel ${ }^{\text {II }}$} & Yes & $230(87.8)$ & 1 & 8 \\
\hline & No & $32(12.2)$ & 0 & 0 \\
\hline \multirow[t]{9}{*}{ Travel regions } & Nordic countries & $134(51.1)$ & 1 & 5 \\
\hline & Baltic countries & $93(35.5)$ & 1 & 3 \\
\hline & Central Europe & $118(45.0)$ & 1 & 6 \\
\hline & Southern Europe & $95(36.3)$ & 1 & 2 \\
\hline & Eastern Europe & $22(8.4)$ & 0 & 0 \\
\hline & Asia & $36(13.7)$ & 1 & 0 \\
\hline & North America & $14(5.3)$ & 0 & 0 \\
\hline & Central America & $4(1.5)$ & 0 & 0 \\
\hline & South America & $4(1.5)$ & 0 & 0 \\
\hline
\end{tabular}




\begin{tabular}{|c|c|c|c|c|}
\hline & $\begin{array}{l}\text { Africa } \\
\text { Australia and Oceania }\end{array}$ & $\begin{array}{l}4(1.5) \\
3(1.1)\end{array}$ & $\begin{array}{l}0 \\
0\end{array}$ & $\begin{array}{l}0 \\
0\end{array}$ \\
\hline \multicolumn{5}{|l|}{ Healthcare-related risk factors } \\
\hline Occupation of household member & Healthcare professional & $18(6.9)$ & 0 & 0 \\
\hline \multirow[t]{2}{*}{ Hospitalised $^{\text {II }}$} & In Finland & $32(12.2)$ & 0 & 1 \\
\hline & Abroad & $2(0.8)$ & 0 & 0 \\
\hline Chronic immunocompromising & Yes & $7(2.7)$ & 0 & 1 \\
\hline \multirow[t]{2}{*}{ disease } & No & $254(96.9)$ & 0 & 8 \\
\hline & Not disclosed & $1(0.4)$ & 0 & 0 \\
\hline \multirow[t]{2}{*}{ Course of oral antibiotics } & Within last month & $16(6.6)(n=241)$ & 0 & 0 \\
\hline & Within last 6 months & $87(34.9)(n=249)$ & $\mathrm{n} / \mathrm{a}$ & 4 \\
\hline $\begin{array}{l}\text { Verified previous colonisation/ } \\
\text { infection with MRSA and/or ESBL } \\
\text { producing Enterobacteriaceae }\end{array}$ & & $0(0.0)$ & 0 & 0 \\
\hline
\end{tabular}

${ }^{\dagger}$ Animal contact was defined as contact with live animals, carcasses or samples of animal origin.

* At least once a week.

$\S$ Less than once a week.

"D During last 12 months.

MRSA: Methicillin-resistant Staphylococcus aureus.

ESBL: Extended-spectrum beta-lactamase.

ESBL/pAmp-C-PE: Extended-spectrum beta-lactamase and/or plasmidic AmpC producing Enterobacteriaceae

- To protect respondent confidentiality information is not published in this table.

n/a not available 
Table 2. Susceptibility profiles of Escherichia coli strains isolated from veterinarians. ${ }^{\dagger}$

\begin{tabular}{lccccccc} 
Strain & CTX & CAZ & FOX & FEP & MEM & CTX-C, CAZ-C & Phenotype \\
\hline EL15E & S & S & S & S & S & -- & -- \\
EL24E & R & R & S & R & S &,++ & ESBL \\
EL120E & R & S & S & R & S &,+- & ESBL \\
EL158E & R & R & S & R & S &,++ & ESBL \\
EL216E & R & R & S & R & S &,++ & ESBL \\
EL233E & R & R & S & R & S &,++ & ESBL \\
EL245E & R & R & S & R & S &,++ & ESBL \\
EL256E & R & R & S & R & S &,++ & ESBL \\
EL259E & R & R & S & R & S &,++ & ESBL \\
EL298E & R & R & R & R & S &,++ & ESBL+AmpC
\end{tabular}

\footnotetext{
${ }^{\dagger}$ Inhibition zone diameters were measured following the European Committee on Antimicrobial Susceptibility Testing (EUCAST) standard guidelines (EUCAST, 2013) and results interpreted according to EUCAST epidemiological cut-off values.

₹ extended-spectrum beta-lactamase producer

CTX: cefotaxime $5 \mu \mathrm{g}$ CAZ: ceftazidime $10 \mu \mathrm{g}$ FOX: cefoxitin $30 \mu \mathrm{g}$ FEP: cefepime $30 \mu \mathrm{g}$ MEM: meropenem $10 \mu \mathrm{g}$ CTX-C: cefotaxime $30 \mu \mathrm{g}$ and cefotaxime/clavulanic acid $30 \mu \mathrm{g} / 10 \mu \mathrm{g}$ CAZ-C: ceftazidime $30 \mu \mathrm{g}$ and ceftazidime/clavulanic acid $30 \mu \mathrm{g} / 10 \mu \mathrm{g}$

S: susceptible, R: resistant, -- not performed, + positive result, - negative result.
} 
Table 3. Characteristics of extended-spectrum beta-lactamase (ESBL) producing Escherichia coli isolates carried by Finnish veterinarians.

\begin{tabular}{|c|c|c|c|c|c|c|c|c|c|c|c|c|c|c|c|c|c|c|c|c|c|}
\hline 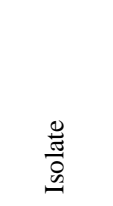 & 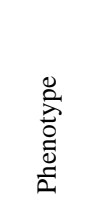 & 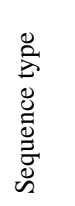 & 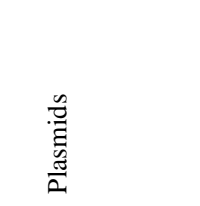 & 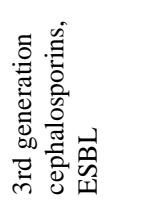 & 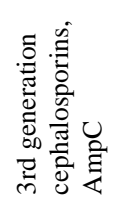 & 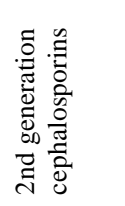 & 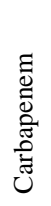 & 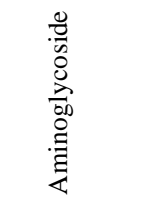 & 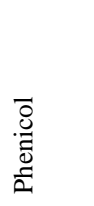 & 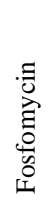 & 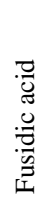 & 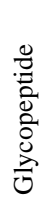 & 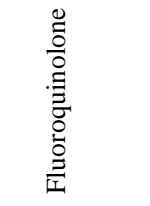 & 疍 & 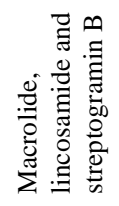 & 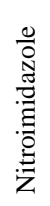 & 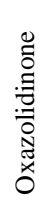 & 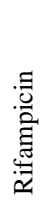 & 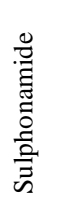 & 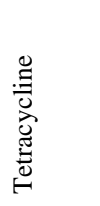 & 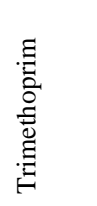 \\
\hline EL15E & $S$ & 1431 & IncFIB, IncFIC & - & - & $b l a_{\mathrm{TEM}-1 \mathrm{~A}}$ & - & $\begin{array}{c}\text { strA } \\
\text { straB } \\
\text { aad5A }\end{array}$ & - & - & - & - & - & - & $m p h(A)$ & - & - & - & $\begin{array}{l}\text { sull } \\
\text { sul2 }\end{array}$ & $\operatorname{tet}(A)$ & $d f r A 17$ \\
\hline EL24E & ESBL & 131 & $\begin{array}{c}\text { IncFII, } \\
\text { IncFIA, IncX4, } \\
\text { IncFIB, } \\
\text { Col(BS512), } \\
\text { Col156 }\end{array}$ & $b l a_{\mathrm{CTX}-\mathrm{M}-27}$ & $b l a_{\mathrm{CMY}-76}$ & - & - & $a a c\left(6^{\prime}\right) I f$ & - & - & - & - & - & - & - & - & - & - & - & - & - \\
\hline EL120E & ESBL & 450 & $\begin{array}{c}\text { IncB/O/K/Z, } \\
\text { IncFIB, IncFII, } \\
\text { IncFIA, Coll56, } \\
\text { Col(BS512), } \\
\text { Col(KPHS6) }\end{array}$ & $b l a_{\text {СТХ-м-14 }}$ & - & $b l a_{\mathrm{TEM}-1 \mathrm{~B}}$ & - & - & - & & - & - & & - & - & & - & - & & - & - \\
\hline EL158E & ESBL & 10 & $\begin{array}{c}\text { IncII, IncFIB } \\
\text { IncFII }\end{array}$ & $b l a_{\mathrm{CTX}-\mathrm{M}-1}$ & - & - & - & - & - & - & - & - & - & - & - & - & - & - & sul2 & $\operatorname{tet}(A)$ & - \\
\hline EL216E & ESBL & 131 & $\begin{array}{l}\text { IncFII, IncFIA, } \\
\text { IncFIB }\end{array}$ & $b l a_{\text {СТХ-М-15 }}$ & - & - & - & $\operatorname{aad} A 2$ & - & - & - & - & - & - & $\begin{array}{l}m p h(A) \\
\operatorname{erm}(B)\end{array}$ & & - & - & sull & - & drfA 12 \\
\hline EL233E & ESBL & 80 & $\begin{array}{c}\text { IncFII, } \\
\operatorname{Col}(B S 512)\end{array}$ & $b l a_{\mathrm{CTX}-\mathrm{M}-14}$ & - & - & - & - & - & - & - & - & - & - & - & - & - & - & - & - & - \\
\hline EL245E & ESBL & 963 & $\begin{array}{l}\text { IncII, IncFII, } \\
\text { IncFIB, IncFIB }\end{array}$ & $b l a_{\mathrm{CTX}-\mathrm{M}-1}$ & - & - & - & - & - & - & - & - & - & - & - & - & - & - & sul2 & $\operatorname{tet}(A)$ & - \\
\hline EL256E & ESBL & 131 & $\begin{array}{l}\text { IncFII, IncFIB, } \\
\text { IncY, } \\
\text { IncB/O/K/Z }\end{array}$ & $b l a_{\mathrm{CTX}-\mathrm{M}-15}$ & - & $b l a_{\mathrm{TEM}-1 \mathrm{~A}}$ & - & $\begin{array}{c}\text { straA } \\
\text { straB } \\
\operatorname{aad}(3) I I d\end{array}$ & - & - & - & - & - & - & - & - & - & - & - & - & - \\
\hline EL259E & ESBL & 871 & $\begin{array}{c}\operatorname{IncFII,~IncR,} \\
\operatorname{IncY}, \text { IncXI }\end{array}$ & $b l a_{\mathrm{SHV}-12}$ & - & $b l a_{\mathrm{TEM}-1 \mathrm{~A}}$ & - & $\begin{array}{c}\text { aadA1 } \\
\text { aadA2 } \\
\operatorname{aad}(3) I I a \\
\operatorname{aph}\left(3^{\prime}\right) I I a\end{array}$ & $\begin{array}{l}\text { floR } \\
\text { cmlAl }\end{array}$ & - & - & - & $Q n r S 1$ & - & Inu $(F)$ & - & - & - & sul3 & $\operatorname{tet}(A)$ & $d f r A l$ \\
\hline EL298E & $\begin{array}{l}\text { ESBL+ } \\
\text { AmpC }\end{array}$ & 648 & $\begin{array}{c}\text { IncFIA, IncFIB, } \\
\text { IncFII }\end{array}$ & $b l a_{\mathrm{CTX}-\mathrm{M}-15}$ & - & $b l a_{\mathrm{OXA}-1}$ & - & $\begin{array}{l}a a c\left(6^{\prime}\right) I b c r \\
\text { aadA5 }\end{array}$ & catB3 & - & - & - & $a a c\left(6^{\prime}\right) I b c r$ & - & $m p h(A)$ & - & - & - & sull & $\operatorname{tet}(B)$ & dfrA17 \\
\hline
\end{tabular}

S: Susceptible to 3rd generation cephalosporins. - not detected. 
Table 4. Virulence gene detection by VirulenceFinder 1.5 (Joensen et al., 2014) in livestockassociated methicillin-resistant Staphylococcus aureus CC398 isolated from veterinarian.

\begin{tabular}{lc} 
Virulence gene & $+/-$ \\
\hline$h l b$ & + \\
$h l g \mathrm{ABC}$ & + \\
$t s t$ & - \\
$l u k \mathrm{ED}$ & - \\
$l u k \mathrm{FS}-\mathrm{PV}$ & - \\
etAB & - \\
edinABC & - \\
aur & + \\
spc $\mathrm{ABE}$ & - \\
scn & - \\
sak & - \\
$\mathrm{ACME}$ & - \\
SeA-E, G-O, R, U, Q & - \\
& \\
+ detected; - not detected
\end{tabular}

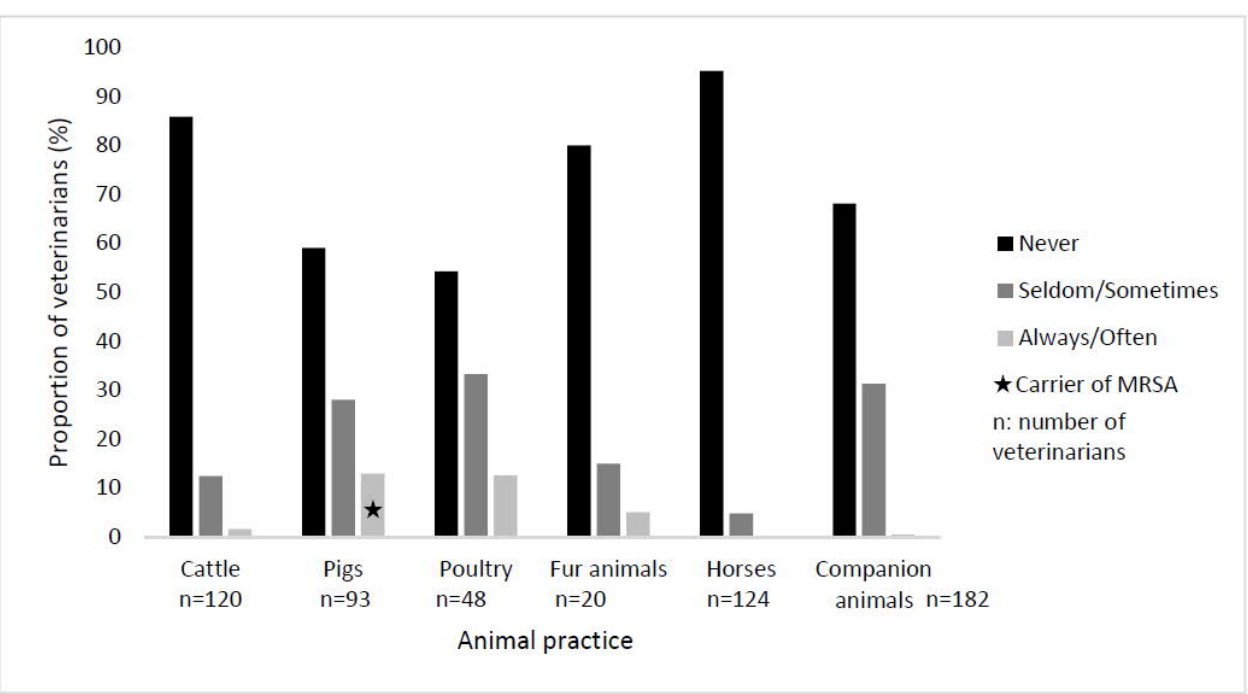

Figure 1. Use of dust masks by veterinarians in animal practice. (Surgical procedures and dental care excluded.) 